\title{
Narcissism And Accounting Majors
}

\author{
Jill Brown, Ph.D. Candidate at Oklahoma State University, USA \\ Michael D. Akers, Ph.D., Marquette University, USA \\ Don E. Giacomino, Ph.D., Marquette University, USA
}

\begin{abstract}
Narcissism is a personality trait that varies in individuals much like other characteristics. Accordingly, narcissism can positively or negatively impact the leadership style and career of business leaders. While personality research has examined the level of narcissism in college-aged students over the past 30 years, only recently has limited research examined narcissism in business students. Prior research has not examined accounting students. Using the Narcissistic Personality Inventory (NPI), we assess the level of narcissism in accounting students at a public and private institution in the Midwest. Our findings show accounting students have a lower level of narcissism than other business students, both undergraduate and graduate, and the general population of college-age students. We find differences in the level of narcissism by gender and whether the student is a leader, or not, in student organizations. We also discuss implications for accounting education.
\end{abstract}

Keywords: Accounting Major; Personality Trait; Narcissism; Leadership

\section{INTRODUCTION}

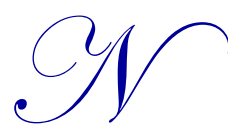

arcissism" is the personality trait of egotism, vanity, conceit, or simple selfishness. Applied to a social group, it is sometimes used to denote elitism or an indifference to the plight of others. The name "narcissism" was coined by Freud (1914) after Narcissus, who in Greek myth was a pathologically self-absorbed young man who fell in love with his own reflection in a pool. Freud believed that some narcissism is an essential part of all of us from birth. Andrew P. Morrison (1997) claims that, in adults, a reasonable amount of healthy narcissism allows the individual's perception of his needs to be balanced in relation to others. Some experts (Business Day, 2011) believe a disproportionate number of pathological narcissists are at work in the most influential reaches of society such as medicine, finance and politics.

DuBrin (2012, vii) notes that the degree of narcissism can have varying degrees of impact on an individual's career:

A healthy dose of narcissism can facilitate career success, because reasonable concern with the self helps a person think of achieving important goals and being admired as a leader. The moderately narcissistic person often appears to be self-confident and charismatic. Yet extreme narcissism can hamper success because the narcissist irritates and alienates others in the workplace as well as in personal life.

The most commonly-used measures to assess narcissism are the Narcissistic Personality Inventory (NPI) and the Millon Clinical Multiaxial Inventory (MCI). The NPI measures narcissism as it occurs in the general population (i.e., normal narcissism), whereas the MCI measures narcissistic personality disorder. Since our study focuses on healthy narcissism and does not attempt to measure narcissistic personality disorder, we use the NPI.

In this paper, we use the NPI to assess narcissism of college accounting majors (members/candidates of Beta Alpha Psi) from a public state university and a private university in the Midwest. The Narcissistic Personality Inventory (NPI) measures narcissism in total and for seven categories of narcissism. While other research has examined narcissism of business students, undergraduate and graduate, this is the first study to examine narcissism of accounting students. The paper is organized in the following manner. In the next section, we investigate research that primarily focused on narcissism of college and business students. We develop our hypotheses in Section 3. In 
Section 4, we describe our sample and methodology, followed by a discussion of the results in Section 5. Section 6 discusses the implications of our study for accounting educators and the final section provides suggestions for further research.

\section{LITERATURE REVIEW}

Our review of prior research focused on studies that examined narcissism in college and business students as well as studies that examined the relationship of narcissism with skills necessary to be successful in business. We didn't find any studies that assessed narcissism of accounting students.

Twenge et. al (2008b) tested for changes in narcissism scores of college students from 1979 to 2006 and found an increase in the NPI for campuses across the country, however Twenge et al. (2008a) noted no changes in the NPI (total scores) among California college students. They attributed the difference for California to the cultural and ethnic shifts at the University of California campuses during the period studied. Twenge et al. (2008a) referred to the Trzesniewski et. al study (2008) which measured the NPI of students at the University of California campuses from 1979 to 2007 and compared those results with the Twenge et al. (2008a) study's results. Both studies show no change in NPI for California college students.

Carroll (1987) examined narcissism of MBA students to determine the relationships between narcissism scores and the motives for affiliation, intimacy and power. Carroll found a significant difference in narcissism between men and women. Carroll states that previous studies (Raskin \& Hall, 1981: Emmons, 1984; Watson, Grisham, Trotter \& Biderman, 1984; Biscardi \& Schill, 1985) using the NPI with samples of college-age students "converge in suggesting a profile of the highly narcissistic individual". Carroll (1987) also found that narcissism was positively correlated with the need for power and negatively correlated with the need for intimacy.

Two teams of psychology professors have recently studied narcissism among business students. Brown et. al (2010) surveyed business students to study their psychological profiles and how they felt they would act in certain ethical situations. The researchers did not use the NPI; instead they had students answer a range of selfism (narcissism) questions and empathy questions and the students reacted to an "ethical" situation. The researchers concluded that students who are accounting and finance majors are more likely to act unethically when compared to students who are management and marketing majors.

Brunell et. al. (2008) conducted two separate studies involving college students and one involving business managers in an MBA program. The studies focused on the relationship between narcissism and leadership. In the first undergraduate study, students were measured on various personality traits, including narcissism. Then, students were put into groups and told to choose a leader. Students who scored higher on the desire for power (one dimension of narcissism) were more likely to say they wanted to lead the group and were more likely to be viewed as leaders by other members of the group. In the MBA student study, the students rated highest in narcissism were most likely to be identified as emerging leaders by the expert observers.

Westerman et al. (2012) collected data from 536 undergraduates (Millennial students) at Appalachian State University to compare narcissism levels of undergraduate business and psychology students, evaluate whether business classroom activities impact narcissism and determine whether narcissism influences salary and career expectations. Their results indicate that current college students have significantly higher levels of narcissism than previous students, business students have significantly higher levels of narcissism than psychology students, narcissism doesn't have a significant relationship with business classroom activities and narcissists expect to significantly have more career success with respect to finding a job, salary and promotions. Westerman et al. cite prior research that shows a relationship between narcissism and academic entitlement (Greenberger, Lessard, Chen and Farruggia, 2008), and individuals higher in narcissism often exhibit hypersensitivity to evaluation and potential criticism (Beck, Freeman \& Associates, 1990; Bushman and Baumeister, 1998), are more likely to be very poor team players, blame others for failures, be overly competitive and take credit for success (Campbell, Reeder, Sedikides and Elliot, 2000). They further note that narcissists have higher self-esteem and are more extraverted (Emmons, 1984), have increased short-term likeability (Oltmanns, Friedman, Fiedler and Turkheimer, 2004; Paulhus, 1998), demonstrate enhanced performance on public evaluation tasks (Wallace and Baumeister, 2002), and 
demonstrate emergent leadership (Blair, Hoffman and Helland, 2008; Brunell, Gentry, Campbell, and Kuhnert, 2006; Galvin, Waldman and Balthazard, 2010; Resick, Whitman, Weingarden, and Hiller, 2009). Westerman et al also cite research that links high levels of narcissism with the following negative behaviors that would impact any type of business or accounting firm: white-collar crime (Blickle, Schlegel, Fassbender and Klein, 2006), assault (Bushman, Bonacci, van Dijk and Baumeister, 2003), aggression (Bushman and Baumeister, 1998), distorted judgments of one's abilities (Paulhus, Harms, Bruce and Lysy, 2003), rapidly depleting common resources (Campbell, Bush, Brunell and Shelton, 2005), risky decision making (Campbell, Goodie and Foster, 2004), alcohol abuse (Luhtanen and Crocker, 2005). Additionally, narcissistic managers are likely to build toxic, unproductive work environments (Lubit, 2002).

\section{HYPOTHESES}

Our sample is comprised of college accounting majors from two different mid-western universities-one public, and one private. Given that there is no prior literature or theory on narcissism that would distinguish public university students from private university students, we do not predict that there will be differences between the two.

H1: There are no statistically significant differences between accounting students at private and public institutions for individual narcissism traits or categories of narcissism.

Prior literature has found mixed results when it comes to narcissism and gender. Twenge et al. (2008), Foster et. al (2003), Bushman and Baumeister (1998), Farwell and Wohlwend-Lloyd (1998), Carroll (1987) found that males scored higher on the NPI than females while Irvine (2009) found that for the period 2002-2007, women were developing narcissistic traits at four times the rate of men. Because of this change, we do not hypothesize which gender will display higher narcissism.

H2: There are no statistically significant differences between female and male accounting students for individual narcissism traits or categories of narcissism.

We know of no prior studies that examined the relationship between narcissism and leadership in college students. However, we expect student leaders to display higher narcissism levels than non-leaders since Authority is one category of narcissism.

H3: Student leaders have significantly higher levels of narcissism than non-leaders.

As previously noted, Twenge et al. (2008) examined narcissism of American college students over the period, 1979-2006 and found that narcissism scores on the NPI rose from a mean score of 15.02 in 1979 to 17.29 in 2006. Westerman et al. (2012) found a 17.06 mean score for all millennial students in their study with business students having a mean score of 17.67. While this is the first study of accounting students, they are still business students. Accordingly, we would expect the mean score from the NPI of accounting students to approximate the mean of business students found in the Westerman et al. study.

H4: The mean level of narcissism for accounting students in our study will approximate the mean level of business students in the Westerman et al. (2012) study.

\section{SAMPLE AND METHODOLOGY}

Our sample consists of 120 college accounting majors who were either candidates or members of Beta Alpha Psi during the time of our study. Of the 120 students, 61 attended a public state university, and 59 attended a private university. Of the total sample, 55 percent were male, 45 percent of the total sample indicated that they held a leadership position, and 54 percent of leaders were male.

The NPI is the most widely used measure of narcissism in social psychological research (http://en.wikipedia.org/wiki/Narcissistic_Personality_Inventory). Although several versions of the NPI have been proposed in the literature, a forty-item, forced-choice version (Raskin \& Terry, 1988) is the one most commonly 
employed in current research. The NPI is based on the DSM-III clinical criteria for narcissistic personality disorder (NPD), although it was designed to measure these features in the general population. Thus, the NPI is often said to measure "normal" or "subclinical" (borderline) narcissism (i.e., people who score very high on the NPI do not necessarily meet criteria for diagnosis with NPD). The reliability and validity is evidenced by prior research (Raskin and Terry, 1988; Rhodewalt and Morf, 1995) as Cronbach's alpha was .83.

The NPI (see Exhibit 1) consists of 40 questions each of which has two choices (A or B). Respondents choose only A or B. One of the responses is considered narcissistic while the other is considered non-narcissistic. Respondents can score themselves by assigning one point for each response that matches the key. One point is scored for the answer " $\mathrm{A}$ " for the following questions $(1,2,3,6,8,11,12,13,14,16,21,24,25,27,29,30,31,33$, $34,36,37,38$, and 39) and one point is scored for the answer "B" for all other questions. This yields the respondent's total score.

Then, responses are grouped into seven component traits as shown below:

\begin{tabular}{llll} 
Trait & \multicolumn{1}{c}{ Questions (answered according to key, 1 point for each question) } \\
Authority & $1,8,10,11,12,32,33,36$ & & \\
Self-sufficiency & $17,21,22,31,34,39$ & & \\
Superiority & $4,9,26,37,40$ & & \\
Exhibitionism & $2,3,7,20,28,30,38$ & \\
Exploitativeness & $6,13,16,23,35$ & & \\
Vanity & $15,19,29$ & & \\
Entitlement & $5,14,18,24,25,27$ &
\end{tabular}

According to Young \& Pinsky (2009), "There's no such thing as a good or bad result on this test. Scoring high on the narcissism inventory, or high on any of the component categories, doesn't mean you have a disorder, or that you're a good or bad person." Young \& Pinsky (2009) indicate that it is important to consider which traits are dominant. For example, they state that an overall score that reflects more points on vanity, entitlement, exhibitionism and exploitativeness is more cause for concern than someone who scores high on authority, selfsufficiency and superiority.

\section{RESULTS}

Table 1 presents the findings of our study. The overall score and the score for each of the seven categories are shown for the entire sample, by type of school (public, private), gender and leadership (leader or non-leader).

Table 1

NPI Results

\begin{tabular}{lcccccccc}
\hline & Total Score & Authority & $\begin{array}{c}\text { Self- } \\
\text { Sufficiency }\end{array}$ & Superiority & Exhibitionism & Exploitativeness & Vanity & Entitlement \\
\hline Total & 15.750 & 4.683 & 2.900 & 2.025 & 1.683 & 1.700 & 1.042 & 1.717 \\
\hline Public & 15.836 & 4.557 & 3.066 & 1.984 & 1.574 & 1.738 & 1.082 & 1.836 \\
Private & 15.661 & 4.814 & 2.729 & 2.068 & 1.797 & 1.661 & 1.000 & 1.593 \\
\hline Males & 15.530 & 4.727 & 2.894 & 1.909 & 1.621 & 1.606 & $0.894^{*}$ & $1.879^{*}$ \\
Females & 15.923 & 4.673 & 2.885 & 2.135 & 1.788 & 1.750 & $1.250^{*}$ & $1.442^{*}$ \\
\hline Non- & 14.939 & $4.227^{*}$ & 2.924 & 1.955 & $1.500^{*}$ & 1.576 & 1.061 & 1.697 \\
Leaders & 16.741 & $5.241^{*}$ & 2.870 & 2.111 & $1.907^{*}$ & 1.852 & 1.019 & 1.741 \\
Leaders & 16 & & & & & & &
\end{tabular}

We do not find any statistically significant difference between state school and private school students for the total narcissism score or for any of the traits. In fact, the only difference is found in Item (question) \#10 ("I am not sure if I would be a good leader."), in which private school students (average 0.86) score higher than state school students (average 0.72). The difference is significant at a five percent level. 
More differences are found between males and females. While the difference in total scores is not significant, males and females score differently in the Vanity and Entitlement traits. In the Vanity category, females scored higher, the average values for males and females are 0.89 and 1.25 , respectively. This difference is significant at the 10 percent level. In the Entitlement category, males scored higher; the average values for males and females are1.88 and 1.44, respectively. This difference is also significant at the 10 percent level.

As hypothesized, students who hold leadership positions scored higher on the NPI than students who do not. Leaders have an average total score of 16.740, while non-leaders have an average total score of 14.939. This difference is significant at the 10 percent level. Leaders also score higher in the Authority and Exhibitionism traits. For Authority, average scores for leaders and non-leaders are 5.241 and 4.227, respectively. This difference is highly significant (1 percent level). For Exhibitionism, average scores for leaders and non-leaders are 1.907 and 1.500 , respectively. This difference is statistically weaker, and is significant at the 11 percent level.

For our sample of college accounting majors, the average total score is 15.75 . This score is considerably lower than the 17.67 score for undergraduate business students in the Westerman et al. (2012) study and 2006 score of 17.29 for college students in the Twenge et al. study (2008). Using the NPI, Foster et. al. (2003) surveyed 3445 people from six continents. They found an NPI average of 15.2 and 15.3 for the world and U.S. samples, respectively. Young and Pinsky (2009) used the NPI to measure narcissism of celebrities and MBAs; then, compared them with Foster's results. Overall, we found that the NPI results show accounting majors to be less narcissistic than undergraduate students, MBA students and celebrities. The average NPI score of 15.750 for accounting majors was slightly higher than 15.3 for the general U.S. population, but below the averages for MBAs (16.18) and celebrities (17.84).

By trait, we found that of the seven traits, accounting majors were less narcissistic than celebrities and MBAs on four traits (Self-sufficiency, Exhibitionism, Vanity, Entitlement), had mixed results on two traits (Authority and Exploitativeness) and scored higher than both of the other groups on only one trait (Superior). While our results differ from the findings of other studies that examined college and specifically, business students, the findings aren't entirely surprising. Both institutions have excellent Beta Alpha Psi chapters that are actively involved in community service. The private school emphasizes ethics throughout the entire curriculum. As DuBrin $(2012,66)$ notes:

...all business schools emphasize the study of business ethics and social responsibility. As a result, many people who study business and management might become less narcissistic, and more driven toward helping others, as a result of their studies.

Table 2 contains a summary of those results by trait.

Table 2

Comparison of NPI Across Studies

\begin{tabular}{|c|c|c|c|c|c|c|c|c|}
\hline Group & $\begin{array}{l}\text { Total } \\
\text { Score }\end{array}$ & Authority & $\begin{array}{c}\text { Self- } \\
\text { Sufficiency }\end{array}$ & Superiority & $\begin{array}{c}\text { Exhibit- } \\
\text { ionism }\end{array}$ & $\begin{array}{c}\text { Exploi- } \\
\text { tativeness }\end{array}$ & Vanity & Entitlement \\
\hline Accounting Majors & 15.75 & 4.68 & 2.9 & 2.03 & 1.68 & 1.7 & 1.04 & 1.72 \\
\hline Celebrities & 17.84 & 5.04 & 3.37 & 1.75 & 2.54 & 1.98 & 1.19 & 1.99 \\
\hline MBA's & 16.18 & 4.63 & 3.19 & 1.86 & 1.73 & 1.62 & 1.19 & 1.97 \\
\hline
\end{tabular}

\section{IMPLICATIONS}

We see several implications and potential applications of our study. First, accounting educators can always benefit from knowing more about their students. For example, comparing the scores of undergraduate accounting majors to the scores of MBA students reveals some differences. Educators might want to tailor their teaching styles based on which type of students they are teaching. Second, following the findings of Goncalo et. al (2010) that having two or more narcissists on a team improves performance, measuring the narcissism of students could lead to better group formation for group projects in classes. While the Goncalo et. al (2010) findings may not generalize to in-class projects for accounting majors, future research could determine if this is a superior way to assign group projects. 
Finally, our findings shed some light on the characteristics of student leaders. Knowing that leaders score higher in the Authority and Exhibitionism traits, as well as on the total narcissism score, can give educators more insight into how to mentor and develop leaders. Leaders appear to be more comfortable taking responsibility and making decisions (Authority), and are more content to be the center of attention (Exhibitionism). This knowledge is useful for educators who work with both student leaders and non-leaders. For example, when mentoring a student who is already a leader, an educator might focus on decreasing the strength of the Exhibitionism trait. A leader needs to be comfortable in the spotlight, but should also learn to focus on the wellbeing of the people being led. On the other hand, when trying to develop leadership qualities in a non-leader, an educator would know that the student's Authority and Exhibitionism traits might both need to be increased.

\section{CONCLUSION}

We assessed narcissism in 120 college level accounting majors, and discovered significant differences between males and females and between student leaders and non-leaders. These findings can help accounting educators to become more effective in the classroom and in mentoring students outside of the classroom.

This study makes two specific contributions. First, our study is the first one to examine narcissism of accounting students and thus, addresses the recommendation by Westerman et al. (2012) for future narcissism research at other schools of business. Second, our findings add to the narcissism literature of college-age students.

\section{LIMITATIONS OF THE STUDY}

This study has limitations which might cause the results to not be representative. First, the participants don't represent a random sample of accounting majors as only Beta Alpha Psi members/candidates completed the NPI. Second, while the participants are from both a private and a public institution, both institutions are located in the Midwest.

\section{FUTURE RESEARCH}

Future research might compare accounting majors with other types of business majors (finance, marketing, information technology, human resources, etc.) or compare accountants at different levels of education (undergraduate, Masters, $\mathrm{PhD}$ ). Since accounting faculty have the ability to influence their students, it would be interesting to examine narcissism levels of accounting faculty. In addition, measuring narcissism in accounting professionals would give educators insight into how to best prepare their students for the workforce.

\section{AUTHORS INFORMATION}

Jill Brown, MSA, PhD Candidate at Oklahoma State University, School of Accounting, 401 Business Building, Spears School of Business, Oklahoma State University, Stillwater, Oklahoma 74078-4011 USA. E-mail: jill.brown@okstate.edu

Michael D. Akers, PhD, CPA, CMA, CFE, CIA, Charles T. Horngren Professor and Department Chair, Department of Accounting, College of Business Administration, PO Box 1881, Marquette University, Milwaukee, WI 5320118881 USA. E-mail: michael.akers@ marquette.edu (Corresponding author)

Don E. Giacomino, PhD, CPA, Professor and Flynn Chair Holder, Department of Accounting, College of Business Administration, PO Box 1881, Marquette University, Milwaukee, WI 53201-18881 USA. E-mail: don.giacomino@marquette.edu

\section{REFERENCES}

1. Amernic, Joel and Russell J. Craig. 2010. Accounting as a Facilitator of Extreme Narcissism. Journal of Business Ethics September 2010, Vol. 96, Nr. 1, 79-93.

2. Beck, A. T., A. Freeman \& Associates. 1990. Cognitive Therapy of Personality Disorders New York, NY: Guilford Press. 
3. Bergman, J., Westerman, J., and Daly, J. 2010. Narcissism in Management Education. Academy of Management Learning and Education 9(1), March 2010, 119-131.

4. Biscardi, D., and T. Schill. 1985. Correlations of Narcissistic Traits with Defensive Style, Machiavellianism, and Empathy. Psychological Reports 57: 354.

5. Blair, C. A., B. J. Hoffman, and K. R. Helland. 2008. Narcissism in organizations: A multisource appraisal reflects different perspectives. Human Performance 21, 254-276.

6. Blickle, G., A. Schlegel, P. Fassbender and U. Klein. 2006. Some personality correlates of business whitecollar crime. Applied Psychology: An International Review 55, 220-233.

7. Brown, T.A., J. A. Sautter, L. Littvay, A.C. Sautter, and B. Barnes. 2010. Ethics and Personality: Empathy and Narcissism as Moderators of Ethical Decision Making in Business Students. Journal of Education for Business 85(4), 203-208.

8. Brunell, A. B., W. Gentry, W. K. Campbell, and K. Kuhnert. 2006. Narcissism and emergent leadership. Poster presented at the annual meeting of the Society for Personality and Social Psychology, Palm Springs, CA.

9. Brunell, Amy B., Gentry, William A., Campbell, W. Keith, Hoffman, Brian J., Kuhnert, Karl W. and DeMarree, Kenneth G. (2008). Leader emergence: The case of the narcissistic leader. Personality and Social Psychology Bulletin 34, 1663-1676.

10. Bushman, B. J. and R. F. Baumeister. 1998. Threatened egotism, narcissism, self-esteem, and direct and displaced aggression: Does self-love or self-hat lead to violence? Journal of Personality and Social Psychology 75, 219-229.

11. Bushman, B. J., A. M. Bonacci, M. van Dijk, and R. F. Baumeister. 2003. Narcissism, sexual refusal, and aggression: Testing a narcissistic reactance model of sexual coercion. Journal of Personality and Social Psychology 84, 1027-1040.

12. Business Day 2011/01/07. Megalomiacs abound in politics/medicine/finance http://www.bdlive.co.za/articles/2011/01/07/megalomiacs-abound-in-politicsmedicinefinance

13. Campbell, W. K., C. P. Bush, A. B. Brunell, and J. Shelton. 2005. Understanding the social costs of narcissism: The case of the tragedy of the commons. Personality and Social Psychology Bulletin 31, 13581368.

14. Campbell, W. K., A. S. Goodie, and J. D. Foster. 2004. Narcissism, confidence, and risk-attitude. Journal of Behavioral Decision Making 17, 297-311.

15. Campbell, W. K., G. D. Reeder, C. Sedikides and A. Elliot. 2000. Narcissism and comparative selfenhancement strategies. Journal of Research in Personality 34, 329-347.

16. Carroll, Lynne. (1987) A Study of Narcissism, Affiliation, Intimacy, and Power Motives among Students in Business Administration. Psychological Reports 61, 355-358.

17. DuBrin, Andrew J. (2012) Narcissism in the Workplace Research, Opinion and Practice. Northampton, MA: Edward Elgar Publishing, Inc.

18. Emmons, R. A. 1984. Factor Analysis and Construct Validity of the Narcissistic Personality Inventory. Journal of Personality Assessment 48, 291-300.

19. Farwell, L. and R. Wohlwend-Lloyd. (1998). Narcissistic processes: Optimistic expectations, favorable self-evaluations, and self-enhancing attributions. Journal of Personality 66, 65-83.

20. Freud, Sigmund. 1914). On Narcissism: An Introduction. The Standard Edition of the Complete Psychological Works of Sigmund Freud London: Hogarth Press.

21. Foster, J.D., W.K. Campbell and J.M. Twenge. 2003. Individual Differences in Narcissism: Inflated Selfviews across Lifespan and around the World. Journal of Research on Personality 37, 469-486.

22. Galvin, B. M., D. A. Waldman, and P. Balthazard. 2010. Visionary communication qualities as mediators of the relationship between narcissism and attributions of leader charisma. Personnel Psychology 63, 509537.

23. Goncalo, Jack A., Francis J. Flynn and Sharon H. Kim. 2010. Are Two Narcissists Better Than One? The link Between Narcissism, Perceived Creativity, and Creative Performance. Personality and Social Psychology Bulletin November 2010, Vol.36, Nr.1, 1484-1495.

24. Greenberger, E., J. Lessard, J. C. Chen, and S. P. Farruggia. (2008). Self-entitled college students: Contributions of personality, parenting, and motivational factors. Journal of Youth and Adolescence 37, 1193-1204. 
25. Irwine, M. 2009. May 22. Princess pedestal: How many girls are on one? Daily Herald http://heraldextra.com/lifestyle/article_50a8f46b-fa01-514d-90ec4eac94ec2.html

26. Lubit, R. 2002. The long-term organizational impact of destructively narcissistic managers. Academy of Management Executive 16, 127-138.

27. Luhtanen, R. K. and J. Crocker. 2005. Alcohol use in college students: Effect of level of self-esteem, narcissism, and contingencies of self-worth. Psychology of Addictive Behaviors 19, 99-103.

28. Morrison, Andrew P. 1997. Shame: The Underside of Narcissism. The Analytic Press. ISBN 0-88163-2805.

29. Oltmanns, T. F., J. N. W. Friedman, E. R. Fiedler and E. Turkheimer. 2004. Perceptions of people with personality orders based on thin slices of behavior. Journal of Research in Personality 38, 216-229.

30. Paulhus, D. L. 1998. Interpersonal and intrapsychic adaptiveness of trait self-enhancement: A mixed blessing? Journal of Personality and Social Psychology 74, 1197-1208.

31. Paulhus, D. L., P. D. Harms, M. N. Bruce, and D. C. Lysy. 2003. The over-claiming technique: Measuring self-enhancement of ability. Journal of Personality and Social Psychology 84, 890-904.

32. Raskin, R. N. and C. S. Hall. 1979. A Narcissistic Personality Inventory. Psychological Reports 45, 590.

33. Raskin, R. N. and C. S. Hall. 1981. The Narcissistic Personality Inventory: Alternate-form Reliability and Further Evidence of Construct Validity. Journal of Personality Assessment 45, 159-162.

34. Raskin, Robert and Howard Terry. 1988. A Principal-Components Analysis of the Narcissistic Personality Inventory and Further Evidence of Its Construct Validity. Journal of Personality and Social Psychology, Vol. 54, No. 5, 890-902.

35. Resick, C. J., D. S. Whitman, S. M. Weingarden, and N. J. Hiller. 2009. The bright-side and dark-side of CEO personality: Examining core self-evaluations, narcissism, transformational leadership, and strategic influence. Journal of Applied Psychology 94, 1365-1381.

36. Rhodewalt, F. and C. C. Morf. 1995. Self and Interpersonal Correlates of the Narcissistic Personality Inventory: A Review and New Findings. Journal of Research in Personality 29, 1-23.

37. Trzesniewski, R. H., M. B. Donnellan and R. W. Robbins. 2008. Is "Generation Me" really more narcissistic than previous generations? Journal of Personality 76, 903-917.

38. Twenge, J. M., S. Konrath, J. D. Foster, W. K. Campbell, and B. J. Bushman. 2008a. Further evidence of an increase in narcissism among college students. Journal of Personality 76, 919-927.

39. Twenge, J. M., S. Konrath, J. D. Foster, W.K. Campbell and B. J. Bushman. 2008b. Egos inflating over time: A cross-temporal meta-analysis of the Narcissistic Personality Inventory. Journal of Personality 76, 876-901.

40. Wallace, H. M. and R. F. Baumeister. 2002. The performance of narcissists rises and falls with perceived opportunity for glory. Journal of Personality and Social Psychology 82, 819-834.

41. Watson, P., S. Grisham, M. Trotter, and M. Biderman. 1984. Narcissism and Empathy: Validity Evidence for the Narcissistic Personality Inventory. Journal of Personality Assessment 48, 301-305.

42. Westerman, James W., Jacqueline Z. Bergman, Shawn M. Bergman, and Joseph Daly. (2012). Are Universities Creating Millenial Narcissistic Employees? An Empirical Examination of Narcissism in Business Students and Its Implications. Journal of Management Education 36(1), 5-32.

43. Young, S. Mark and Drew Pinsky. 2009. The Mirror Effect: How Celebrity Narcissism Is Seducing America. HarperCollins Publishers: New York, NY. 


\section{EXHIBIT1}

\section{Narcissistic Personality Quiz}

Based upon the Narcissistic Personality Inventory (NPI)

Instructions: Below is a list of 40 statements, one in Column A and the opposite in Column B. For each statement, choose the item from Column A or B that best matches you (even if it's not a perfect fit). The quiz takes most people between 5 and 10 minutes to finish. Please respond to all questions

\section{$\underline{\mathbf{A}}$}

\begin{tabular}{|c|c|c|}
\hline 1. & & I have a natural talent for influencing people. \\
\hline 2. & & Modesty doesn't become me. \\
\hline 3. & & I would do almost anything on a dare. \\
\hline 4. & & $\begin{array}{l}\text { When people compliment me I sometimes get } \\
\text { embarrassed. }\end{array}$ \\
\hline 5. & & $\begin{array}{l}\text { The thought of ruling the world frightens the hell out } \\
\text { of me. }\end{array}$ \\
\hline 6. & & I can usually talk my way out of anything. \\
\hline 7. & & I prefer to blend in with the crowd. \\
\hline 8. & & I will be a success. \\
\hline 9. & & I am no better or worse than most people. \\
\hline 10. & & I am not sure if I would make a good leader. \\
\hline 11. & & I am assertive. \\
\hline 12. & & I like to have authority over other people. \\
\hline 13. & & I find it easy to manipulate people. \\
\hline 14. & & I insist upon getting the respect that is due me. \\
\hline 15. & & I don't particularly like to show off my body. \\
\hline 16. & & I can read people like a book. \\
\hline 17. & & $\begin{array}{l}\text { If I feel competent I am willing to take responsibility } \\
\text { for making decisions. }\end{array}$ \\
\hline 18. & & I just want to be reasonably happy. \\
\hline 19. & & My body is nothing special. \\
\hline 20. & & I try not to be a show off. \\
\hline 21. & & I always know what I am doing. \\
\hline 22. & & I sometimes depend on people to get things done. \\
\hline 23. & & Sometimes I tell good stories. \\
\hline 24. & & I expect a great deal from other people. \\
\hline 25. & & I will never be satisfied until I get all that I deserve. \\
\hline 26. & & Compliments embarrass me. \\
\hline 27. & & I have a strong will to power. \\
\hline 28. & & I don't care about new fads and fashions. \\
\hline 29. & & I like to look at myself in the mirror. \\
\hline 30. & & I really like to be the center of attention. \\
\hline 31. & & I can live my life in any way I want to. \\
\hline 32. & & Being an authority doesn't mean that much to me. \\
\hline 33. & & I would prefer to be a leader. \\
\hline 34. & & I am going to be a great person. \\
\hline 35. & & People sometimes believe what I tell them. \\
\hline 36. & & I am a born leader. \\
\hline 37. & & $\begin{array}{l}\text { I wish somebody would someday write my } \\
\text { biography. }\end{array}$ \\
\hline 38. & & $\begin{array}{l}\text { I get upset when people don't notice how I look } \\
\text { when I go out in public. }\end{array}$ \\
\hline 39. & _ & I am more capable than other people. \\
\hline 40. & & I am much like everybody else. \\
\hline
\end{tabular}

\section{$\underline{\mathbf{B}}$}

I am not good at influencing people. I am essentially a modest person.

I tend to be a fairly cautious person.

I know that I am good because everybody keeps telling me so.

If I ruled the world it would be a better place.

I try to accept the consequences of my behavior.

I like to be the center of attention.

I am not too concerned about success.

I think I am a special person.

I see myself as a good leader.

I wish I were more assertive.

I don't mind following orders.

I don't like it when I find myself manipulating people.

I usually get the respect that I deserve.

I like to show off my body.

People are sometimes hard to understand.

I like to take responsibility for making decisions.

I want to amount to something in the eyes of the world.

I like to look at my body.

I will usually show off if I get the chance.

Sometimes I am not sure of what I am doing.

I rarely depend on anyone else to get things done.

Everybody likes to hear my stories.

I like to do things for other people.

I take my satisfactions as they come.

I like to be complimented.

Power for its own sake doesn't interest me.

I like to start new fads and fashions.

I am not particularly interested in looking at myself in the mirror.

It makes me uncomfortable to be the center of attention.

People can't always live their lives in terms of what they want.

People always seem to recognize my authority.

It makes little difference to me whether I am a leader or not.

I hope I am going to be successful.

I can make anybody believe anything I want them to.

Leadership is a quality that takes a long time to develop.

I don't like people to pry into my life for any reason.

I don't mind blending into the crowd when I go out in public.

There is a lot that I can learn from other people.

I am an extraordinary person. 


\section{$\underline{\text { Demographic data }}$}

Academic standing: Junior Senior Master

Gender: Female Male

Indicate your major (Select all that apply): __ Accounting Information Technology Marketing Economics Finance Human Resources __ Other (please indicate)

Indicate if you have a leadership position in a student organization or extracurricular activity (for example, Office of Beta Alpha Psi, IMA, Chess Club or any other student group: captain of the volleyball team, etc.)

_Yes __No 